http://dx.doi.org/10.4314/jae.v16i2.5

\title{
Attitude and Knowledge of Print Media Journalists towards Reporting of Climate Change News in Nigeria
}

\author{
C. J. Amu and A. E. Agwu \\ Department of Agricultural Extension \\ University of Nigeria, Nsukka \\ Enugu State, Nigeria \\ E-mail: ebonamu@yahoo.com;ekwe.agwu@unn.edu.ng; \\ agwuekwe@hotmail.com
}

\begin{abstract}
Valid knowledge is important as it predisposes journalists to report with precision, yet journalists' behaviours need to be influenced so as to increase awareness and dissemination of climate change news. The study investigated the attitude of print media journalists towards the coverage of climate change news in Nigeria. One hundred and fifty journalists who specialized in the area of science, environment and social sciences were randomly selected from ten national dailies namely: Daily Sun, Guardian, Daily Champion, ThisDay, The Nation, The Punch, Daily Times, Daily Independent, Business Day and Vanguard newspapers and interviewed. Data were analyzed using frequency, percentage, mean scores, and multiple regression. Majority of the journalists' perceived the Internet $(M=2.67 ; S . D=0.79)$ as being the most important source of climate information. Majority (73.1\%) of the journalists lacked training in reporting climate change issues. Majority statistics of the journalists had favourable attitude towards reporting of climate change issues. Some personal characteristics, namely, sex, training in reporting climate change issues and years in service influenced journalists' attitudes towards coverage of climate change news. The study recommended that training of agricultural communicators should receive appropriate attention in universities in order to ensure that personnel with adequate training in agriculture and communication are not in shortfall in media organizations.
\end{abstract}

Key words: Climate change news, journalists' perception and information. 


\section{Introduction}

Global climate change is a phenomenon that has received increasing attention in the last decade. The attention is motivated by assertions that Africa has had her fair share of food insecurity and starvation, ignorance and disease as well as widespread poverty. Most of the disasters hitting Africa are climate related. However, the media, which has an important influence on the society, has failed to clearly link climate, disasters and society (Rod, Richard and Ambika, 2006).

If people get climate information well in time it could help them develop mitigation strategies to cope with the looming dangers. According to Luganda (2008) if the important connection between climate information and the negative extreme events can be established and relayed to the end users, intervention strategies could be taken ahead of time. By understanding, planning for and adapting to a changing climate, individuals and societies can take advantage of opportunities and reduce risks. Looking at contemporary events, there is need to develop the capacity of the media to achieve this goal.

Many African photojournalists have captured and documented best-known climate stories which were disseminated by global networks. These stories have connected the continent with starvation, the effects of droughts and floods with records of people and animals dying, poverty, and many other attendant social evils linked to the climate. The non- adaptive and mitigation stories that fail to make connections between the public and climate science are in many ways what are considered to be the African climate stories by the media. Although a lot of useful climate information exists within the science community, it has been rendered of little significance to the ordinary public because it has been difficult for journalists to comprehend valid climate knowledge, and also dissemination channels are not well developed.

It has also been observed that the media have a poor understanding of the climate change debate and express little interest in it. The complicated language aside, most of the climate information is often considered boring and unexciting, as practicing journalists have testified (Rod, Richard and Ambika, 2006). The media is not doing enough in depth analysis of the climate factors that may be causing the disasters. Neither do they deliberately and as a strategy, develop specialized reporters on climate issues, let alone science writers. The media mainly focus on what the politicians are saying; they do not seek scientists' input (Sundblad, 2008).

The dissemination of climate information influences decision making as the individuals, communities or governments make informed decisions because all humans are implicated to varying degrees in contributing to sources of greenhouse gas emissions - through household activities, engagement in industrial activities, consumption and transport. Hence, valid knowledge is important as it predisposes journalists to report with precision, which will in turn 
enable people to react and to develop strategies to minimize the negative consequences of global climate change.

It is journalists' behaviour that needs to be influenced to increase awareness and dissemination of climate change news. There are grounds to conclude that knowledge may effect behavioural changes. Knowledge is the foundation of a process in which attitudes, norms and perceptions of possibilities to act are carefully monitored to clarify and decide between behavioural alternatives (Sundblad, 2008).

Therefore, armed with useful climate information, the media can help to add value to climate issues by getting more relevant inputs from related sectors and provide a wealth of useful information that can help decision making. Unfortunately, this is not taking place with the climate reporting and related stories coming out of Africa. According to Lunganda (2008) several reasons as opined by practicing journalists in many countries on the continent suggest that the very nature of the subject matter is predominantly boring and uninspiring; and that insufficient exposure to the subject is big hindrance.

This brings to the fore the investigation of print media journalists attitude towards climate change news coverage in Nigeria. The questions relates to what are the personal characteristics of the journalists involved in reporting climate change news? What are the information sources considered important by the journalists in reporting climate change news? What are the knowledge levels of the journalists? Again, what are the journalists' attitudes towards the coverage of climate change news? This study was designed to provide answers to the questions posed above.

\section{Objectives of the Study}

The study sought to examine the print media journalists' attitude towards coverage of climate change news in Nigeria. Specifically the study sought to:

1. identify journalists' information sources about climate change;

2. determine the knowledge level of journalists on agriculture- related climate change issues;

3. assess journalists attitudes towards agriculture-related climate change news; and

4. ascertain the influence of journalists personal characteristics on their attitude towards the coverage of agriculture-related climate change news.

\section{Methodology}

A purposive sampling technique was used in selecting ten (10) national dailies based on their daily circulation potentials relative to other newspapers. To draw a representative sample, a simple random sampling method was used in selecting 15 journalists that specialized in science, environmental and social science 
journalism giving a total sample size of 150 . However, valid responses for analysis were obtained from a total of 104 journalists.

To measure the personal characteristics of the journalists, relevant questions were asked on the journalists' sex, age, educational level, area of academic specialization, area of job specialization, professional status, and years in service. To identify the journalists' important information sources about climate change, a three point Likert-type scale of highly important $=3$, important $=2$, not important $=1$, was used to measure the basis of how important they considered the listed sources of information on climate change. The values on the Likert-type scale were added and the product was divided by 3 to get a mean score of 2.0; hence variables with mean scores of 2.0 or above were regarded as important sources.

To determine the knowledge level of journalists on agriculture- related climate change issues, 20 knowledge based questions on climate change were asked and these questions elicited what respondents knew about climate change. The respondents were to respond "yes" or "no" to the questions. Each time a respondent gave an answer that indicated correct knowledge; a score of 1 was given. Each of the respondents was categorized based on their scores into:

- high knowledge: 14-20 correct responses of the 20 questions;

- moderate knowledge: 7-13 correct responses of the 20 questions;

- low knowledge: 1-6 correct responses of the 20 question; and

- no knowledge: no correct answers to any of the 20 questions.

To assess journalists' attitude towards agriculture-related climate change news, favourable and unfavourable statements were randomly mixed and arranged in a Likert-type format with five response options of strongly agree (5), agree (4), undecided (3), disagree (2) and strongly disagree (1) scaled 5 to 1, respectively, such that the values were added to obtain 15 , with a mean score of 3 . Therefore, statements with mean scores of above 3.00 were regarded as those that the respondents agreed to the issues raised as regards coverage of climate change news. On the other hand, statements with mean scores of below 3.00 were regarded as those that the respondents disagreed with the issue raised as regards coverage of climate change news. In line with the above, means of above 3.00 for favourable statements were regarded as positive attitudes, while for unfavourable statements were regarded as negative attitudes. Also means of below 3.00 for favourable statements were regarded as negative attitudes but positive for unfavourable statements.

To ascertain the influence of journalists' personal characteristics on their attitude towards the coverage agriculture-related climate change news, a regression model was employed. In general, frequency, percentage, mean score, mean deviation, and regression were used for data analysis. 


\section{Results and Discussion}

\section{Socio-Economic Characteristics of Respondents}

Data in Table 1 show that majority (74.0\%) of the journalists were males. This implies that male journalists dominated the newspaper institutions and by implication, this maybe due to the fact that climate change news reporting/ journalism is a time-consuming profession and the responsibility for domestic work is still primarily on the woman. Asa (2010), reports that climate change journalism remains a great challenge for female journalists. Majority (53.8\%) were within the age range of 31 - 40 years. The mean age of the journalists was 34.3 years, indicating that the journalists were predominantly in their active ages and hence high productive stage.

Table 1 also indicates that over $90 \%$ of the journalists have educational qualification higher than school certificate with $45.2 \%$ of the journalists having first degree certificate, while $29.8 \%$ had HND certificates. About $12 \%$ of the respondents had Master's degree and OND certificates, respectively. Only $2.0 \%$ had school certificate/ GCE. This foregoing analysis shows that the respondents were highly educated and this debunks the earlier assertion that journalism in Nigeria is a dumping ground for drop-outs (Olowu and Yahaya, 1993).

The result in Table 1 shows that $14.4 \%$ of the respondents academically specialized in mass communication/ broadcast journalism, while $13.5 \%$ and $10.6 \%$ specialized in sociology and languages, respectively. Meanwhile, $8.7 \%$ and $7.7 \%$ of the respondents studied microbiology/ biochemistry, and geology/earth science. Respondents who studied agricultural science constituted $5.8 \%$ of the respondents. The result of the study shows that arts and social science journalists predominated in the study with respect to the coverage of climate change. This is similar to Dunwoody and Peters (1992) findings, that a typical journalist in the U.S is less likely to have majored in science than is an average U.S resident.

Data in Table 1 further revealed that $16.0 \%$ of the journalists specialized in environment/ property reporting, $14.7 \%$ specialized in general journalism; $14.2 \%$ in agricultural journalism and $13.8 \%$ were news editors. About $7 \%$ of the journalists were political journalists, while $5.7 \%, 5.2 \%$ and $5.1 \%$ were foreign news journalists, graphic presenters/ IT reporters, and news correspondence/features, respectively.

Data in Table 1 further indicate that majority (73.1\%) of the journalists were not trained in reporting climate change issues/events, while only $26.9 \%$ of the journalists were trained. This agrees with Luganda (2008) findings that identified lack of expertise in climate change issues and lack of training in journalistic skills as major factors constraining journalism. These points to the fact that majority of the journalists who cover agriculture- related climate change news do not have 
any relevant training in the subject matter. The implications of these may probably range from general apathy towards agriculture - related climate change news coverage to gross inaccuracies in reportage.

Greater proportions (61.5\%) of the journalists were in reportorial, while $35.6 \%$ were in editorial. About $3 \%$ of the journalists were columnists. In terms of their years in service, a greater proportion (58.7\%) of the journalists had spent 1-5 years in journalism, while $25.9 \%, 12.5 \%$ and $2.9 \%$ had spent $6-10$ years, $11-15$ years and 16-20 years, respectively. The mean years in service by the journalists were 5.85 years. This finding implies that majority of the journalists had been in the profession for not less than 5 years.

TABLE 1

Percentage distribution of respondents by socio-economic characteristics $(\mathrm{N}=104)$

\begin{tabular}{lr}
\hline Socio-economic characteristics & Mean \\
& $\begin{array}{r}\text { Percentage } \\
(\%)\end{array}$ \\
\hline Sex & 74.0 \\
Female & 26.0 \\
Age (years) & \\
$\leq 30$ & 27.9 \\
$31-40$ & 53.8 \\
$\geq 40$ & 18.3 \\
Educational level & \\
School cert./ GCE & 2.0 \\
OND & 11.5 \\
HND & 29.8 \\
First degree & 45.2 \\
Master's level & 11.5 \\
Area of academic specialization & \\
Mass communication/broadcast journalism & 14.4 \\
Sociology & 13.5 \\
Languages & 10.6 \\
Arts/ humanities & 9.0 \\
Pharmacognosy, microbiology and biochemistry & 8.7 \\
Business management/administration & 8.7 \\
Public administration & 8.3 \\
Geology/earth science & 7.7 \\
Political science & 7.0 \\
Engineering (computer, electronics, etc) & 6.3 \\
Agriculture & 5.8 \\
Area of job specialization & \\
Environment/property & 16.0 \\
General journalism & 14.7 \\
\hline
\end{tabular}




\begin{tabular}{lr}
\hline Agriculture & 14.2 \\
Editing & 13.8 \\
Politics & 6.7 \\
Foreign news reporters & 5.7 \\
Graphic presentation/IT reporting & 5.2 \\
News correspondents and features & 5.1 \\
Online reporting & 4.8 \\
Education beat & 4.8 \\
Health & 4.7 \\
Business news & 4.3 \\
Training of journalists on climate change & \\
reporting & \\
Yes & 26.9 \\
No & 73.1 \\
Professional status & \\
Reportorial & 61.5 \\
Editorials & 35.6 \\
Columnists & 2.9 \\
Years in service & \\
1-5 years & 58.7 \\
6-10 years & 25.9 \\
11-15 years & 12.5 \\
16- 20 years & 2.9 \\
\hline
\end{tabular}

\section{Perceived Importance of Information Sources}

Data in Table 2 indicate that journalists perceived some information sources to be more important than others with regards to their need of climate change news. Sources perceived as being more important include Internet $(M=2.67 ; S . D=0.79)$, television $(M=2.42 ; S . D=0.68)$, Nigeria ministry of environment $(M=2.40 ; S . D=$ $0.65)$, political leaders $(M=2.39$; $S . D=0.67)$, public opinion $(M=2.38$; $S . D=0.77)$, scientific journal $(M=2.35 ; S . D=0.70)$, newspapers $(M=2.28 ; S . D=0.74)$, developing countries government $(M=2.11 ; S . D=0.66)$, radio $(M=2.08 ; S . D=0.91)$, international agencies $(M=2.02 ; S . D=0.81)$ and developed countries government $(\mathrm{M}=2.01 ; \mathrm{S} . \mathrm{D}=0.77)$.

On the other hand, sources considered of less importance included: twitter ( $M=$ 1.46 ; $S . D=0.68)$, face book ( $M=1.53 ; S . D=0.65)$, blogs $(M=1.58 ; S . D=0.66)$, and ministry of agriculture $(M=1.78 ; S . D=0.72)$. The Table also shows that the standard deviations were all less than 1.0 showing that the journalists' individual scores as regards their opinion on the importance of the information sources did not differ much from the mean score. 
TABLE 2

Perceived importance of the information sources

\begin{tabular}{lcc}
\hline Sources & Mean & S.D \\
\hline Internet & $2.67^{*}$ & 0.79 \\
Television & $2.42^{*}$ & 0.68 \\
Nigeria ministry of environment & $2.40^{*}$ & 0.65 \\
Political leaders & $2.39^{*}$ & 0.67 \\
Public (including opinion survey) & $2.38^{*}$ & 0.77 \\
Scientific journal & $2.35^{*}$ & 0.70 \\
Newspapers & $2.28^{*}$ & 0.74 \\
Academics & $2.13^{*}$ & 0.77 \\
Developing countries government & $2.11^{*}$ & 0.66 \\
Radio & $2.08^{*}$ & 0.91 \\
International agencies & $2.02^{*}$ & 0.81 \\
Developed country government & $2.01^{*}$ & 0.77 \\
Ministry of science \& technology & 1.97 & 0.71 \\
Special interest group & 1.92 & 0.66 \\
Private organization & 1.90 & 0.66 \\
Farm magazines & 1.79 & 0.77 \\
Ministry of agriculture & 1.78 & 0.72 \\
IPCC publication & 1.61 & 0.72 \\
Letters to the editors & 1.61 & 0.70 \\
Blogs & 1.58 & 0.66 \\
Face book & 1.53 & 0.65 \\
Twitter & 1.46 & 0.68 \\
\hline *Important information sources & &
\end{tabular}

\section{Knowledge level of Journalists on Agriculture - Related Climate Change Issues}

Table 3 shows that $78.8 \%$ of the journalists had high knowledge about climate change, $3.8 \%$ of the journalists had low knowledge, while $17.4 \%$ had moderate knowledge of climate change. This result opposes the findings of Luganda (2008) which described the media as being ignorant of climate science. The high knowledge level of the journalists may probably be due to their higher educational level and exposure to the use of ICT tools (e.g. internet) which are more efficient and effective when compared with other traditional information sources. 
TABLE 3

Distribution of respondents on the basis of knowledge level on climate change

\begin{tabular}{ll}
\hline Level of knowledge on climate change & $\%$ \\
\hline No knowledge & 0.0 \\
Low knowledge (1-6 scores) & 3.8 \\
Moderate knowledge (7-13 score) & 17.4 \\
High knowledge (14-20 scores) & 78.8 \\
\hline
\end{tabular}

\section{Attitudes of the Journalists towards the Coverage of Agriculture- Related Climate Change News}

The result (mean and standard deviation) of the responses of the journalists as regards the coverage of agriculture- related climate change news are shown in Table 4. Respondent's agreement with the favourable stated items in the attitude scale indicated positive attitude towards coverage of agriculture- related climate change news, while agreement with unfavourable items indicated negative attitude towards coverage of agriculture- related climate change news.

It is evident from the Table that the respondents had positive attitude towards the coverage of agriculture- related climate change news in most of the statements. Most of the respondents agreed that there is need for close collaboration between journalists and agriculture experts $(M=3.54 ; S . D=0.52)$; news coverage on agricultural climate conditions is necessary for the achievement of increased productivity and income $(M=3.53$; $S . D=0.67)$; climate change news coverage is necessary to generate understanding and co-operation among farmers $(M=3.40$; $S . D=0.73)$; journalists should cover adequately agriculturerelated climate change events in order to save the planet $(M=3.26 ; S . D=0.88)$; agriculture- related climate change news coverage would help to provide better and improved journalist service to farmers and the public $(M=3.26, S . D=0.71)$ and agriculture- related climate change is of high news worthiness $(M=3.09$; $S . D=$ $0.95)$.

On the other hand, the respondents did not agree with the following unfavorable statements: coverage of agriculture- related climate change will lead to conflict between the media owners and the reporters $(M=2.19$; $S . D=1.30)$; newspapers does not reach the rural farmers in their villages, hence there is no need to report on climate change as it relates to agriculture $(M=2.05$; $S . D=1.15)$; many farmers can not afford to purchase newspapers that cover agriculture- related climate change issues $(M=1.94 ; S . D=1.20)$; the coverage of agriculture- related climate change news will not increase farmers' socio-economic status $(M=1.92, S . D=$ 1.21); media houses tend to lose as a result of covering agriculture- related climate change news $(M=1.82 ; S . D=1.29)$ and media owners/editors do not 
appreciate climate change news $(M=1.74 ; S . D=1.00)$. The respondents further disagreed with the statements that the coverage of agriculture- related climate change news will not increase journalists' knowledge of climate science $(M=1.72$; $S . D=1.13)$ and if journalists should give in to cover agriculture- related climate change on a long term basis, they will be committing professional suicide $(M=1.54$; $S . D=0.94)$. The data equally show standard deviations greater than 1.0 indicating that the journalists' individual scores as regards their responses on attitude towards the coverage of agriculture- related climate change news are more spread apart; implying that their responses differed much from the mean score.

Considering the serious climatic impacts on agriculture especially in the area of food security and poverty in Nigeria, the positive attitude about coverage of agriculture- related climate change news suggest the desire of the journalists for a better and improved journalistic service to farmers and the public, and hence agriculture in Nigeria. This assertion could be confirmed by the high mean of 3.53 and 3.26 recorded among journalists' on the items which say that news coverage on agricultural climate conditions is necessary for the achievement of increased productivity and income, and that journalists should cover adequately climate change events in order to save the planet, respectively.

On the other hand, respondents also agreed to the unfavorable statements that reporters consider agriculture- related climate change and environmental issues to be boring $(M=3.43$; $S . D=0.88)$; actually I do not care much about agricultural climate change news $(M=3.18 ; S . D=1.08)$, agricultural related climate change news does not worth any prime space/air time/column $(M=3.30 ; S . D=1.18)$, and that many farmers are not interested in climate change news reported through the print media $(M=3.00 ; S . D=0.89)$. The implication here is that not all the respondents have positive attitude towards the coverage of agriculture- related climate change news in Nigeria.

In general, item 'c which states that there is need for close collaboration between journalists and agricultural experts, recorded the highest mean of 3.54 among the journalists, while the lowest mean of 1.54 was recorded in their response to the statement that "I believe that if journalists' should give in to cover climate change on a long term basis, they will be committing professional suicide".

Although many journalists were willing to take up the task of increasing the coverage of agriculture- related climate change issues, some journalists still actually do not care much about agricultural climate change news. Some reporters consider agriculture- related climate change and environmental issues to be boring. This might be due to journalists not having received training in climatechange reporting; so it is not surprising to see errors in stories about the scientific aspects of the issue. Some respondents perceived agriculture- related climate change news not to worth any prime space/air time/column probably because according to Boykoff and Roberts (2007) climate news stories, and specifically agriculture- related climate change issues competes (often weakly) with other 
more immediate issues for public attention, and this leads to their marginality as media officials are more concerned with local issues like crime and jobs. Most times, news editors decide what to publish partly by asking what has happened this hour, today, or this week. With agricultural climate issues, the answer is often 'very little' (because agriculture is a seasonal activity in most parts of Nigeria) which leads once again to the news media concentrating on events with an immediate impact - like politics and sports. Again, the journalists agreed that the local, national or international political action required to address the problems behind agriculture- related climate change issues moves slowly, and slow-moving events sit uncomfortably in the daily or weekly media timeframe (Paran, 2006). 


\section{TABLE 4}

Mean and standard deviation of the responses of journalists on attitude on coverage of agriculture climate change news

\begin{tabular}{|c|c|c|c|c|}
\hline $\begin{array}{l}\stackrel{\oplus}{E} \\
\stackrel{\Phi}{ \pm}\end{array}$ & Journalists' perception on climate change & $\mathbf{M}$ & S.D & Remark \\
\hline A & $\begin{array}{l}\text { Agricultural related climate change news coverage will not increase } \\
\text { journalists' voice in climate change mitigation and adaptation strategies. }\end{array}$ & $1.72^{*}$ & 1.13 & D \\
\hline B & $\begin{array}{l}\text { News coverage on agricultural climate conditions is necessary for the } \\
\text { achievement of increased productivity and income. }\end{array}$ & 3.53 & 0.52 & A \\
\hline C & $\begin{array}{l}\text { There is need for close collaboration between journalists and agricultural } \\
\text { experts }\end{array}$ & 3.54 & 0.67 & A \\
\hline D & There should be media forum for all climate change experts & 3.00 & 1.17 & A \\
\hline $\mathrm{E}$ & $\begin{array}{l}\text { Local, national or international political action required to address the } \\
\text { problems behind agricultural related climate change issues moves slowly }\end{array}$ & $3.05^{\star}$ & 1.15 & A \\
\hline $\mathrm{F}$ & $\begin{array}{l}\text { Agricultural related climate change news coverage is necessary to generate } \\
\text { understanding and co-operation among farmers }\end{array}$ & 3.40 & 0.73 & A \\
\hline G & $\begin{array}{l}\text { Agricultural related climate change news coverage would help to provide } \\
\text { better and improved journalist service to farmers and the public. }\end{array}$ & 3.26 & 0.71 & A \\
\hline $\mathrm{H}$ & $\begin{array}{l}\text { Journalists should cover adequately climate change events in order to save } \\
\text { the planet }\end{array}$ & 3.26 & 0.88 & A \\
\hline I & $\begin{array}{l}\text { Journalists make agricultural related climate change news to be more } \\
\text { relevant and responsive to the public/farmers information needs }\end{array}$ & 3.16 & 0.87 & A \\
\hline $\mathrm{J}$ & $\begin{array}{l}\text { Journalists are not to be blamed for the low coverage of agricultural related } \\
\text { climate change news }\end{array}$ & $3.14^{*}$ & 0.84 & A \\
\hline $\mathrm{K}$ & Agricultural related climate change is of high news worthiness & 3.09 & 0.95 & A \\
\hline $\mathrm{L}$ & $\begin{array}{l}\text { Agricultural related climate change news does not worth any prime space/air } \\
\text { time/column }\end{array}$ & $3.06^{*}$ & 1.22 & A \\
\hline M & $\begin{array}{l}\text { Reporters consider agricultural related climate change and environmental } \\
\text { issues to be boring. }\end{array}$ & $3.43^{*}$ & 0.88 & A \\
\hline $\mathrm{N}$ & $\begin{array}{l}\text { The coverage of agricultural related climate change news will not increase } \\
\text { farmers' socio-economic status. }\end{array}$ & $1.92^{*}$ & 1.21 & D \\
\hline 0 & $\begin{array}{l}\text { Newspapers does not reach the rural farmers in their villages, hence there is } \\
\text { no need to report on climate change as it relates to agriculture. }\end{array}$ & $2.05^{*}$ & 1.15 & D \\
\hline$P$ & $\begin{array}{l}\text { Media owners/editors do not appreciate agricultural related climate change } \\
\text { news }\end{array}$ & $1.74^{*}$ & 1.00 & D \\
\hline Q & $\begin{array}{l}\text { Many farmers can not afford to purchase newspapers that cover agricultural } \\
\text { related climate change issues. }\end{array}$ & $1.94^{*}$ & 1.20 & D \\
\hline $\mathrm{R}$ & $\begin{array}{l}\text { Coverage of agricultural related climate change will lead to conflict between } \\
\text { the media owners and the reporters. }\end{array}$ & $2.19^{*}$ & 1.30 & D \\
\hline S & $\begin{array}{l}\text { Media houses tends to lose as a result of covering agricultural related } \\
\text { climate change news }\end{array}$ & $1.82^{*}$ & 1.29 & D \\
\hline $\mathrm{T}$ & $\begin{array}{l}\text { I believe that if journalists' should give in to cover climate change on a long } \\
\text { term basis, they will be committing professional suicide }\end{array}$ & $1.54^{*}$ & 0.94 & $\mathrm{D}$ \\
\hline $\mathrm{U}$ & Actually I do not care much about agricultural climate change news. & $3.18^{*}$ & 1.08 & A \\
\hline V & $\begin{array}{l}\text { Coverage of agricultural related climate change news will not increase } \\
\text { journalists knowledge of climate science }\end{array}$ & $1.72^{*}$ & 1.13 & D \\
\hline
\end{tabular}

Statements with asterisks $\left({ }^{*}\right)$ are unfavourable statements

$A=$ agree, $D=$ Disagree (Cut-off point $=3$ )

Source: Field data 2010 


\section{Influence of Personal Characteristics of the Journalists on Attitude towards Reporting Climate Change News}

Table 5 shows the influence of journalists' personal characteristics on attitude towards climate change news. The specified variables were able to explain $45.0 \%$ of the variation in journalists' attitude. The F- ratio ( Fcal $=2.37$ ) which shows the overall significance of the equation was significant at $5 \%$ level of probability.

Estimates of the parameters of the regression analysis revealed that, all the coefficients of the variables of the regression function were positive except educational level, years in service, monthly income and nature of appointment. The coefficient of sex was positive and significant at $5 \%$ level of probability. These findings depict that a unit increase in the number of male journalists reporting climate change news, will led to a corresponding increase in the predisposition towards reporting climate change news. This shows the important influence of journalists' sex on attitude towards the coverage of climate change news. This finding supports the work of Asa (2010) that male journalists are more professional than female journalists; since climate change journalism is a time-consuming profession and the responsibility for domestic work is still primarily on the woman. It is therefore a great challenge for female journalists. Also, men have a higher propensity to take risk than female.

Training in reporting climate change issues contributed positively to the attitudes of journalists and was significant $($ at $p<0.05)$. The direct relationship of journalists training with attitude points to the fact that a unit increase in training of the journalists in climate change reporting will favourably increase their attitude towards the coverage of agriculture- related climate change. This points to the fact that adequate capacity-building and workshops for the journalists will increase journalists' interests to acquire and report relevant climate change news. It will also equip them to better share and exchange information and ideas, which will eventually leads to improved journalistic skills; hence greater predispositions towards the coverage of climate change issues.

However, years in service had a significant negative influence on attitude (at $p<0.01$ ). This shows that the more the number of years of journalists in service, the less predisposed they become in reporting climate change news. This may probably be due to the perception that "journalists' commits professional suicide if they give in to coverage of climate change on a long term basis" (Rod, Richard and Ambika, 2006). The implication of this finding could probably be as a result of low levels of awareness, obstacles to reporting and inability to meet the needs of journalists and media professionals as regards climate change coverage. This finding contradicts the assertions made by Leyser, Kapperman, and Keller (1994) that people with longer years in service tends to have significantly more favourable attitudes than those with little or no years in service. 
TABLE 5

Summary result of regression analysis of socio-economic characteristics of journalists' and their attitude

\begin{tabular}{|c|c|c|c|}
\hline Variables & $\begin{array}{l}\text { Coefficients } \\
\text { (standard error) }\end{array}$ & T & Sig. \\
\hline (Constant) & & 3.97 & 0.00 \\
\hline Sex & 0.43 & 3.05 & $0.00^{*}$ \\
\hline Age & 0.11 & 0.65 & 0.52 \\
\hline Educational level & -0.02 & -0.10 & 0.92 \\
\hline $\begin{array}{l}\text { Area of } \\
\text { specialization }\end{array}$ & 0.08 & 0.53 & 0.60 \\
\hline Area of job specialization & 0.01 & 0.05 & 0.96 \\
\hline $\begin{array}{l}\text { Are you trained in reporting } \\
\text { climate change event }\end{array}$ & 0.29 & 2.01 & $0.05^{\star}$ \\
\hline Religion & 0.03 & 0.21 & 0.84 \\
\hline Professional status & 0.28 & 1.79 & 0.08 \\
\hline Years in service & -0.57 & -2.65 & $0.01^{*}$ \\
\hline $\begin{array}{l}\text { Approximate } \\
\text { income }\end{array}$ & -0.07 & -0.49 & 0.62 \\
\hline Nature of appointment & -0.15 & -0.98 & 0.34 \\
\hline
\end{tabular}

Note: Figure in parenthesis is standard error of the estimate

$$
R^{2}=0.45 \text { (0.23); } R^{2} \text { Adjusted }=0.26 ; F=2.37 ;[p<0.05]
$$

\section{Conclusion and Recommendation}

The study investigated the print media journalists' attitude on the coverage of climate change news in Nigeria. Based on the findings, it was concluded that greater proportion of the respondents perceived the internet as the most important information source, probably because of its efficiency, and reliability. Other major important sources of information on climate change were ministry of environment, political leaders, scientific journals, newspapers, and television. The journalists 
had a high knowledge level of agricultural climate change issues, which were probably due to their higher educational level and exposure to the use of ICTs. However, majority $(73.1 \%)$ of the journalists was not trained in the coverage of climate change news and this could probably result in their lack of interest in reporting climate change stories.

Although many journalists were willing to take up the task of increasing the coverage of agriculture- related climate change issues, some journalists actually do not care much about agricultural climate change news. Some reporters considered agricultural related climate change and environmental issues to be boring.

Based on the major findings, the study therefore recommends that training of agricultural communicators should receive appropriate attention in universities; in order to ensure that personnel with adequate training in agriculture and communication are not in shortfall in media organizations. Moreover, short term courses in agriculture, climate change and other related areas should be organized for journalists to broaden their horizon. Climate change awareness programmes should not be left for the government alone, but should involve stakeholders like religious groups, social groups, youths as well as financial institutions. Ministries of environment and agriculture and NGOs including research/donor organizations such as FAO, ATPS and university institutions should make resources available for training scientists, agricultural extension agents and journalists including editors, to raise their awareness and understanding of the issues around climate change and the importance of their roles in furthering the debate and combating the menace. An online image bank would enable journalists to download and use images in stories on climate change. Also, scientists should simplify the language of climate change to enable everyone to understand their findings.

\section{References}

Asa, S. (2010). To make a mark: A Qualitative Study of Female Journalist's Working Conditions in Ghana. Stockholms Universitet: Ghana.

Boykoff, M.T. and Roberts, J. T. (2007). Media coverage of climate change: current trends, strengths, weaknesses. Human Development Report 2007/8, 
United Nations Development Programme Occasional paper, Human Development Report Office.

Dunwoody, S., and Peters, H. P. (1992). Mass media coverage of technological and environmental risks. Public Understanding of Science. Vol. 1, pp. 199230.

Leyser, Y., Kapperman, G., and Keller, R. (1994). Teacher attitudes toward mainstreaming: A cross-cultural study in six nations. European Journal of Special Needs Education, Vol. 9, pp. 1-15.

Luganda, P. (2008). Opinion: The media, climate and society-the African story [Online]. Retrieved December 18, 2009 from http://www.necjogha.org/taxonomy/term/25.

Olowu, T.A and Yahaya, M.K. (1993). Nigerian journalists attitude toward coverage of rural development news" in Olowu, T.A. (ed.). The Nigerian Journal of Rural Extension and Development. University of Ibadan, Nigeria, Pp 39-48.

Paran, D.Q. (2006). Print media coverage of climate change: why environmental organizations should care, and what they can do to achieve greater coverage. A Master of Arts thesis in the Program of Environmental Studies at Brown University. Rhode Island.

Rod, H., Richard, M., and Ambika, C. (2006). Media Attitudes to Reporting Climate Change. Panos London: Digital Brokdale.

Sunblad, E.-L. (2008). People's knowledge about climate change: Uncertainty as a guide to future commitments. Gothenburg: Department of Psychology.

The Swedish National Encyclopedia, Internet service, 2006-08-29. 